\title{
Effects of Temperature and Light Conditions on Growth of Current-Year Seedlings of Warm- Temperate Evergreen Tree Species and Cool- Temperate Deciduous Tree Species
}

\author{
Koichi Takahashi ${ }^{1}$, Hiroyuki Kobori ${ }^{1}$ and Tatsuyuki Seino ${ }^{2}$ \\ ${ }^{1}$ Department of Biology, Faculty of Science, \\ Shinshu University, Matsumoto, Nagano, \\ ${ }^{2}$ Yatsugatake Forest, Agricultural and Forestry Research Center, \\ Graduate School of Life and Environmental Sciences, \\ University of Tsukuba, Minamimaki, Nagano, \\ Japan
}

\section{Introduction}

It is suggested that global warming affects plant distribution along latitudinal and altitudinal gradients because vegetation changes with thermal conditions. Simulation studies predicted that global warming largely affects plant distribution (e.g., Morin et al., 2008). Actually, vegetation change during several decades has been observed (Penuelas et al., 2007; Lenoir et al., 2008). By contrast, some other studies did not observe vegetation changes (Holtmeier \& Broll, 2007; Harsch et al., 2009). Interpretation of results of simulation models also needs caution because simulation results are different according to modeling methods even for same species (Thuiller, 2003). Therefore, there is still uncertainty of effects of global warming on plant distribution.

Plant distribution is determined by integrated demographic processes such as seed dispersal, seed germination, growth and survival of individual plants. Since early demographic phase such as seedling establishment is more susceptible to environmental conditions than the adult phase (Kullman, 2002), it is important to clarify effects of temperature on seedling growth to predict effects of global warming on plant distribution. There are many experimental studies that examined effects of temperature on growth of tree seedlings (Danby \& Hik, 2007; Hoch \& Körner, 2009; Munier et al., 2010). For example, Yin et al. (2008) reported that seedling growth of Betula albo-sinensis increased in the warm condition with $0.51^{\circ} \mathrm{C}$ higher than the ambient air condition. Many experimental studies that examined effects of temperature were conducted at bright conditions (e.g. Danby \& Hik, 2007; Way \& Sage, 2008). However, most seedlings distribute in dark closed-canopy conditions in forests. Therefore, it is necessary to examine effects of temperature on seedling growth not only in bright conditions but also in dark conditions.

Plants plastically change morphology according to light conditions. For example, relative biomass allocation to leaves is greater in dark conditions than in bright conditions, 
accompanied with reduction of leaf mass per area (LMA) (Ellsworth \& Reich, 1992; Gould, 1993; Niinemets et al., 1999; Takahashi et al., 2005). These morphological changes increase light capture per plant, which is an adaptive strategy in dark conditions. Thus, plants adapt to changing environments through morphological plasticity. This study compared growth responses to temperature and light conditions among three species with different climatically distribution ranges. This comparison is important to clarify effects of global warming on distribution shift of vegetation.

Central Japan is a latitudinal vegetation ecotone between warm-temperate evergreen broadleaved forests and cool-temperate deciduous broad-leaved forests. Ishigami et al. (2003) simulated net primary production (NPP) of forests by the modified model of BIOME3 (Haxeltine \& Prentice, 1996). They predicted that NPP of warm-temperate evergreen broadleaved forests is greater than that of cool-temperate deciduous broad-leaved forests above the current northern distribution limit of warm-temperate evergreen broad-leaved forests if air temperature is increased by global warming. According to the simulation result of NPP, Ishigami et al. (2003) suggested that the northern distribution limit of warm-temperate evergreen broad-leaved forests will move to the north. However, the northern distribution limit would not move to the north easily because of competition with existing northern vegetation (Kohyama \& Shigesada, 1995). Therefore, it is important to compare growth responses of seedlings to temperature and light conditions between warm-temperate evergreen broad-leaved species and cool-temperate deciduous broad-leaved species to clarify vegetation changes due to global warming.

It is considered that warm-temperate evergreen broad-leaved species cannot distribute in the cool-temperate zone due to low winter temperature, not due to low summer temperature for the growth (Kira, 1949). Cold winter temperature decreases photochemical efficiency of leaves in warm-temperate evergreen broad-leaved species (Aranda et al., 2005; Taneda \& Tateno, 2005). Reduction of photochemical efficiency due to cold temperature is more conspicuous in bright conditions than dark conditions (Matsuki et al., 2003). Therefore, it is necessary to examine growth responses to temperature and light conditions not only during growth period but also during dormant period (winter) to clarify how temperature affects growth of warm-temperate evergreen broad-leaved species.

This study examined effects of temperature and light conditions on seedling growth of a warm-temperate evergreen broad-leaved species and two cool-temperate deciduous broadleaved species to answer the following two questions.

(1) Do the warm-temperate evergreen and cool-temperate deciduous broad-leaved species grow more in higher temperature and light conditions?

(2) Do high temperature conditions mitigate reduction of photochemical efficiency in winter for the warm-temperate evergreen broad-leaved species?

\section{Materials and methods}

\subsection{Study site}

This study was conducted at the two sites in Nagano Prefecture, central Japan: the campus of Shinshu University (N36 ${ }^{\circ} 5^{\prime} 04^{\prime \prime}$, E137 $58^{\prime} 41^{\prime \prime}, 630 \mathrm{~m}$ above sea level) in Matsumoto, and the Yatsugatake experimental forest (N35 $56^{\prime} 40^{\prime \prime}, \mathrm{E} 138^{\circ} 28^{\prime} 11^{\prime \prime}, 1350 \mathrm{~m}$ a.s.l.) of Tsukuba University in Nobeyama (Fig. 1). The mean annual precipitation of Matsumoto was 1035.7 mm during 2000-2009. The mean annual temperature was $12.2^{\circ} \mathrm{C}$. The mean monthly 

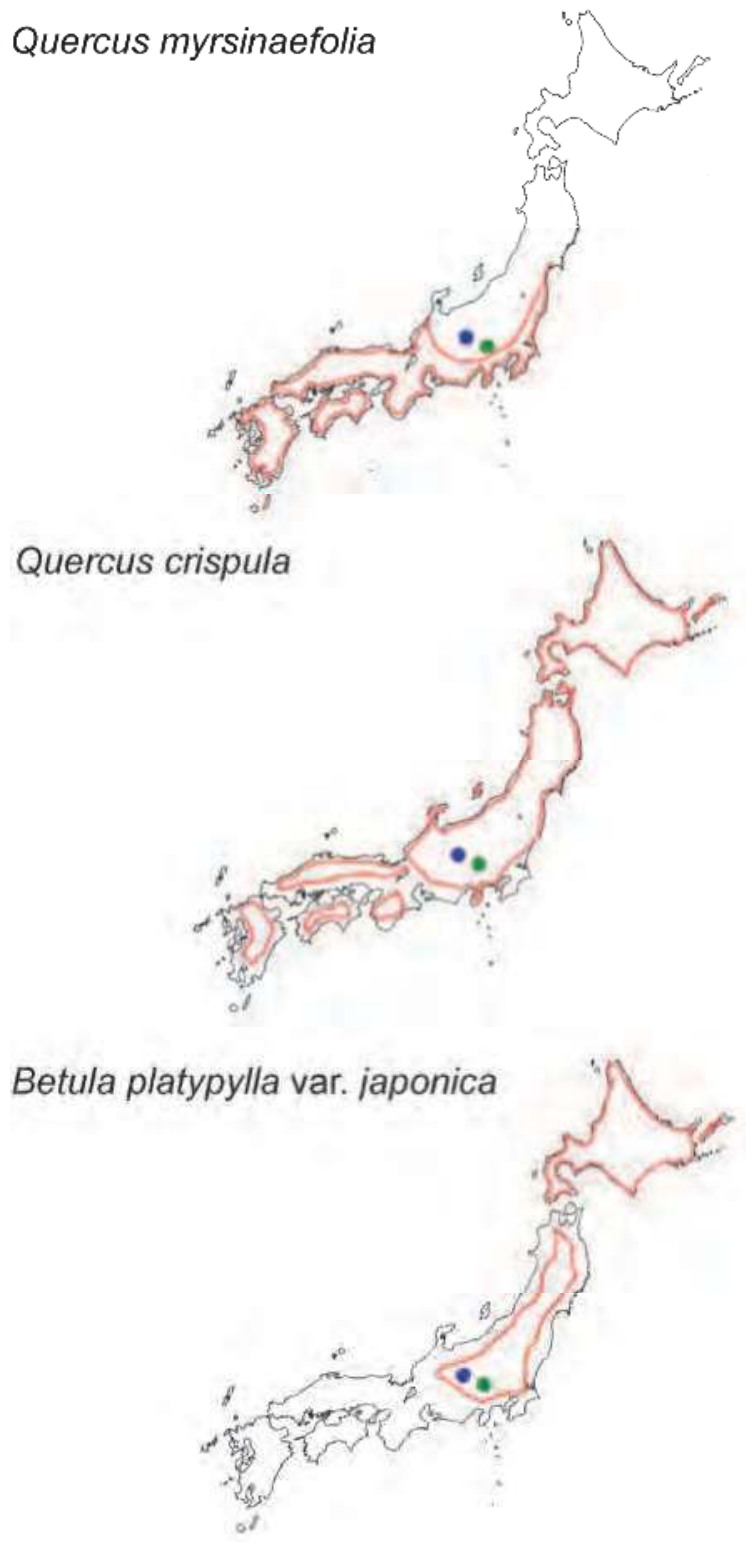

Fig. 1. Distributions (areas surrounded by red lines) of Quercus myrsinaefolia, Q. crispula and Betula platyphylla var. japonica in Japan. Distributions of the two Quercus species and B. platyphylla var. japonica were redrawn from Horikawa (1972) and Okuyama (1982), respectively. Blue and green dots indicate locations of two study sites, Matsumoto and Nobeyama, respectively. 
temperatures in January and in August were -0.3 and $24.8^{\circ} \mathrm{C}$, respectively. The mean annual precipitation of Nobeyama was $1435.3 \mathrm{~mm}$ during 2000-2009. The mean annual temperature was $7.2^{\circ} \mathrm{C}$. The mean monthly temperatures in January and in August were -5.4 and $19.2^{\circ} \mathrm{C}$, respectively.

\subsection{Study species}

This study examined a warm-temperate evergreen broad-leaved species (Quercus myrsinaefolia Blume) and two cool-temperate deciduous broad-leaved species (Betula platyphylla var. japonica Hara and Quercus crispula Blume) (Fig. 1). Q. myrsinaefolia is a shadetolerant tall tree species that distributes in the northern part of warm-temperate zone (Horikawa, 1972). B. platyphylla var. japonica and Q. crispula are shade-intolerant and midshade-tolerant tall tree species, respectively (Samejima, 1979; Koike, 1988; Masaki et al., 1992). B. platyphylla var. japonica and Q. crispula often form pure stands after disturbances such as strong wind, forest fire and clear cutting (Samejima, 1979; Kamitani, 1993; Namikawa et al., 1997).

Q. myrsinaefolia distributes below $700 \mathrm{~m}$ a.s.l. in the warm-temperate zone, and the northern distribution limit is about $\mathrm{N} 38^{\circ}$ (Horikawa, 1972). Distribution of $Q$. myrsinaefolia is limited to below $500 \mathrm{~m}$ a.s.l. in the north of $\mathrm{N} 36^{\circ}$. Although the southern part of Nagano Prefecture was the northern distribution limit of Q. myrsinaefolia (Horikawa, 1972), the distribution of Q. myrsinaefolia is recently observed in central part (Matsumoto area) of Nagano Prefecture probably because of escapes of seeds from planted Q. myrsinaefolia trees (Otsuka \& Ozeki, 2008). B. platyphylla var. japonica distributes in central and northern Japan (Okuyama, 1981). B. platyphylla var. japonica distributes mainly at about $1000 \mathrm{~m}$ and $1300 \mathrm{~m}$ a.s.l. in Matsumoto and Nobeyama, respectively (Editorial Board of Flora of Nagano Prefecture, 1997). Q. crispula is one of the dominant species in cool-temperate deciduous broad-leaved forests, and widely distributes in the cool-temperate zone of Japan (Horikawa, 1972). Q. crispula distributes mainly at about $1000 \mathrm{~m}$ and $1300 \mathrm{~m}$ a.s.l. in Matsumoto and Nobeyama, respectively, like B. platyphylla var. japonica. Therefore, Matsumoto is the northern distribution limit for the warm-temperate evergreen species $Q$. myrsinaefolia, and Nobeyama is optimal thermal conditions for the two cool-temperate deciduous species B. platyphylla var. japonica and Q. crispula.

\subsection{Seedling growth experiments}

Growth experiments were conducted at Matsumoto and Nobeyama to examine effects of temperature and light conditions on the current-year seedling growth of $Q$. myrsinaefolia, $B$. platyphylla var. japonica and $Q$. crispula. A greenhouse experiment was also conducted at Matsumoto to make optimal temperature conditions for the warm-temperate evergreen $Q$. myrsinaefolia because Matsumoto is the northern distribution limit of this species. Windows of the greenhouse were opened in summer to avoid extreme rising of air temperature inside the greenhouse. Increase of air temperature in the greenhouse was $3^{\circ} \mathrm{C}$ on the average. Therefore, air temperature increased in the order of Nobeyama, Matsumoto and the greenhouse at Matsumoto. Nobeyama, Matsumoto and the greenhouse at Matsumoto are referred to T1, T2 and T3, respectively, in this study. Two light conditions (20\% and 54\% light) were set at each temperature condition by using shade cloth. $20 \%$ and $54 \%$ light conditions are referred to L1 and L2, respectively. 


\begin{tabular}{|c|c|c|c|c|c|}
\hline Species & Variables & T & L & T $\times \mathbf{L}$ & $\boldsymbol{n}$ \\
\hline Qm & Stem height & $56.1^{* * *}$ & $<0.1$ & 0.3 & 99 \\
\hline & Stem diameter & $16.1^{* * *}$ & $12.5^{* * *}$ & 0.2 & 46 \\
\hline & Dry mass & $24.2^{* * *}$ & $15.1^{* * *}$ & 1.5 & 46 \\
\hline & LMA & $3.5^{*}$ & $7.0^{*}$ & 1.2 & 47 \\
\hline Qc & Stem height & $46.2^{* * *}$ & 3.1 & 1.3 & 94 \\
\hline & Stem diameter & $18.0^{* * *}$ & $36.2^{* * *}$ & 1.6 & 94 \\
\hline & Dry mass & $11.6^{* * *}$ & $14.2^{* * *}$ & 0.6 & 94 \\
\hline Bp & LMA & $32.4^{* * *}$ & $67.4^{* * *}$ & 0.4 & 93 \\
\hline & Stem height & $517.5^{* * *}$ & 0.4 & 1.0 & 120 \\
\hline & Stem diameter & $768.0^{* * *}$ & $11.5^{* * *}$ & 1.3 & 120 \\
\hline & Dry mass & $595.9^{* * *}$ & $49.5^{* * *}$ & $8.3^{* * *}$ & 117 \\
\hline & LMA & 2.3 & $52.9^{* * *}$ & 2.3 & 109 \\
\hline
\end{tabular}

$*: p<0.05, * *: p<0.01, * * *: p<0.001$.

Table 1. ANOVA results of stem height, stem diameter, seedling dry mass and leaf mass per area (LMA) for Quercus myrsinaefolia (Qm), Quercus crispula (Qc) and Betula platyphylla var. japonica $(\mathrm{Bp})$ to test three temperature conditions $(\mathrm{T})$, two light conditions $(\mathrm{L})$ and the interaction $(\mathrm{T} \times \mathrm{L})$ on the four variables. $F$-values and the number of samples $(n)$ are shown.

Seeds of Q. myrsinaefolia, B. platyphylla var. japonica and Q. crispula were collected in 2008. Seeds were sown in plastic pots (diameter $15 \mathrm{~cm} \times$ height $13 \mathrm{~cm}$ ) filled with horticulture soil and leaf mold. The number of pots was 20 for each light condition (L1 and L2) at each temperature condition (T1, T2 and T3) for each species. Seed sowing was conducted between late March and early April in 2009. However, seeds of B. platyphylla var. japonica were sown again at T1 in early June because seeds did not germinate. Pots were watered once a week or according to the need during the experiment period. All pots were randomly moved within each treatment once a week to minimize effects of pot position on seedling growth.

Seedlings of the three species were excavated and washed carefully in early October in 2009 after the cease of the current-year growth. In terms of Q. myrsinaefolia, only the half number of seedlings was excavated at each light and temperature condition, and the other seedlings were remained for the measurement of photochemical efficiency (see next paragraph). Stem diameter at the base and stem height were measured at the harvest for the three species. Seedlings were divided into stem, root and leaf, and then all leaves were scanned by using the free graphic software ImageJ (http://rsbweb.nih.gov/ij/) to measure total leaf area per seedling. Each organ was oven-dried at $80^{\circ} \mathrm{C}$ for two days, and was weighed.

The ratio of light-induced variable to maximum fluorescence of chlorophyll (Fv/Fm) of $Q$. myrsinaefolia was measured as a surrogate for photochemical efficiency of PSII (DemmigAdams et al., 1989). Photochemical efficiency was measured around the noon once a month from summer of 2009 to the next summer by using a chlorophyll fluorometer OS-30p (OptiScience, NH, USA). The measurement was conducted after 30 min of dark acclimation.

Two-way ANOVA was done to examine effects of temperature and light conditions on stem height, stem diameter, LMA and seedling dry mass (including root) for the three species $(Q$. myrsinaefolia, B. platyphylla var. japonica and Q. crispula). 

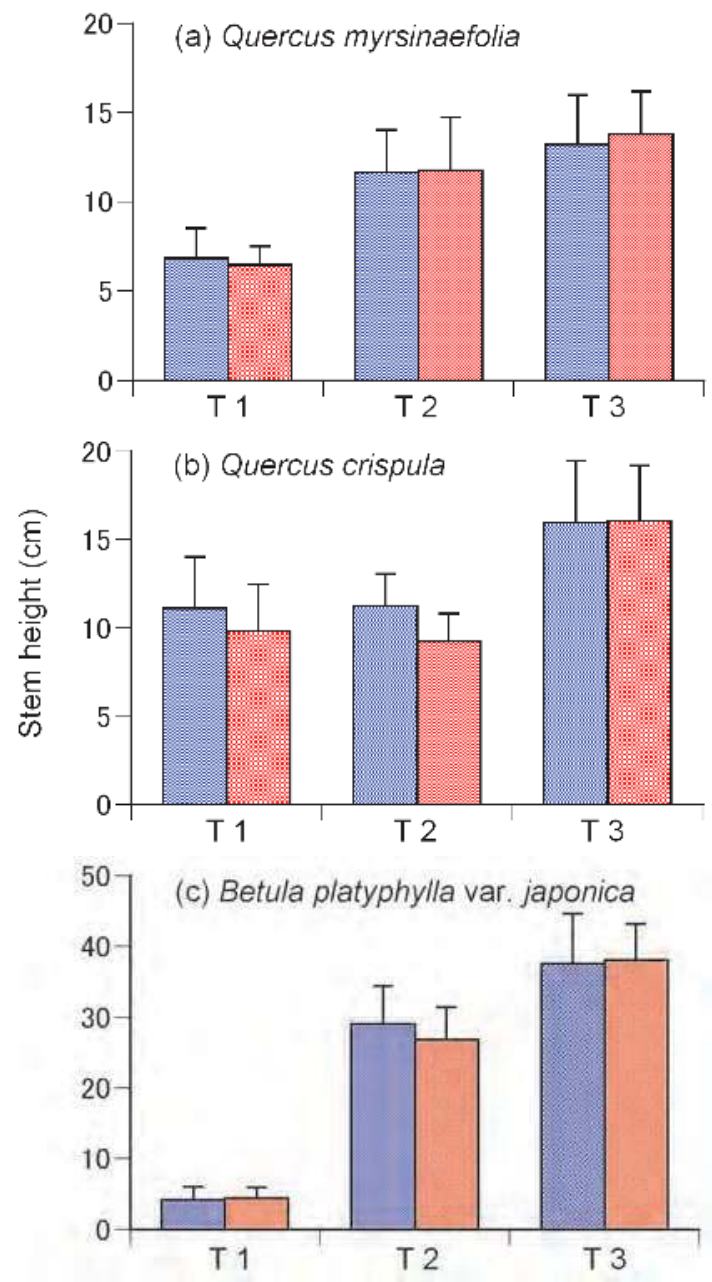

Fig. 2. Stem height for the three species at the three temperature and two light conditions. Blue and red bars indicate L1 and L2 light conditions, respectively. Mean values with positive standard deviations are shown. 

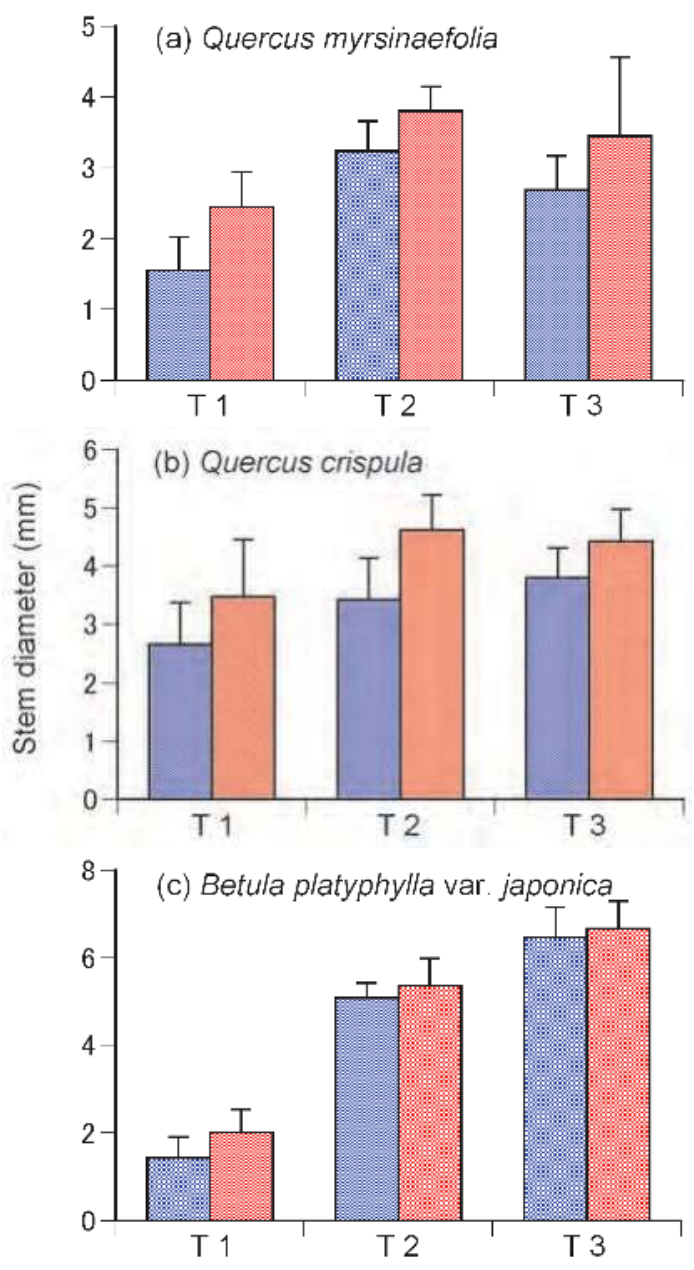

Fig. 3. Stem diameter for the three species at the three temperature and two light conditions. Blue and red bars indicate L1 and L2 light conditions, respectively. Mean values with positive standard deviations are shown.

\section{Results}

\subsection{Growth of the three species}

Effect of temperature on stem height was significant for the three species (Table 1), i.e., stem height was greater in higher temperature conditions, irrespective of light conditions (Fig. 2). However, stem height of Q. crispula was not different between T1 and T2 because of the shoot re-growth from the base after the shoot die-back in late May at T2. The difference in stem height of $Q$. myrsinaefolia between T2 and T3 was also not large (Fig. 2). Light conditions did not affect stem height for the three species (Table 1). By contrast, stem diameter of the three species was different not only among the three temperature conditions 
but also between the two light conditions (Table 1). Stem diameter of the three species was greater at L2 than L1 for each temperature condition (Fig. 3). Stem diameter was greater at $\mathrm{T} 2$ and $\mathrm{T} 3$ than $\mathrm{T} 1$ for Q. crispula. Stem diameter of B. platyphylla var. japonica increased in the order of T1, T2 and T3. However, stem diameter of Q. myrsinaefolia was slightly smaller at $\mathrm{T} 3$ than $\mathrm{T} 2$ for the two light conditions.
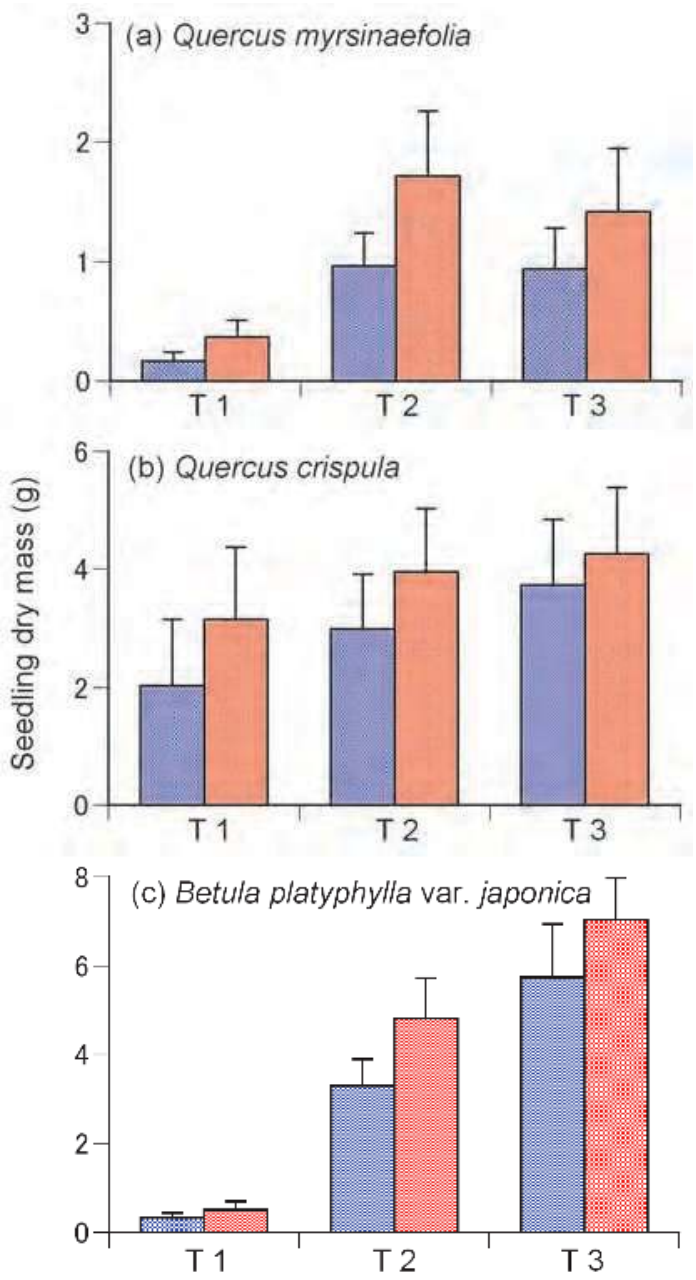

Fig. 4. Seedling dry mass for the three species at the three temperature and two light conditions. Blue and red bars indicate L1 and L2 light conditions, respectively. Mean values with positive standard deviations are shown.

Effects of temperature and light conditions on seedling dry mass were significant for the three species (Table 1), i.e., seedling dry mass was greater at higher temperature and brighter light conditions (Fig. 4). However, seedling dry masses of Q. myrsinaefolia at T3 were similar to and smaller than those at T2 for L1 and L2, respectively. 
LMA was greater at L2 than L1 for the three species (Fig. 5, Table 1). LMA of Q. myrsinaefolia and $Q$. crispula was significantly different among the three temperature conditions (Table 1 ). Although LMA of the two species was greater at T2 than T1 and T3, the difference was not large (Fig. 5).
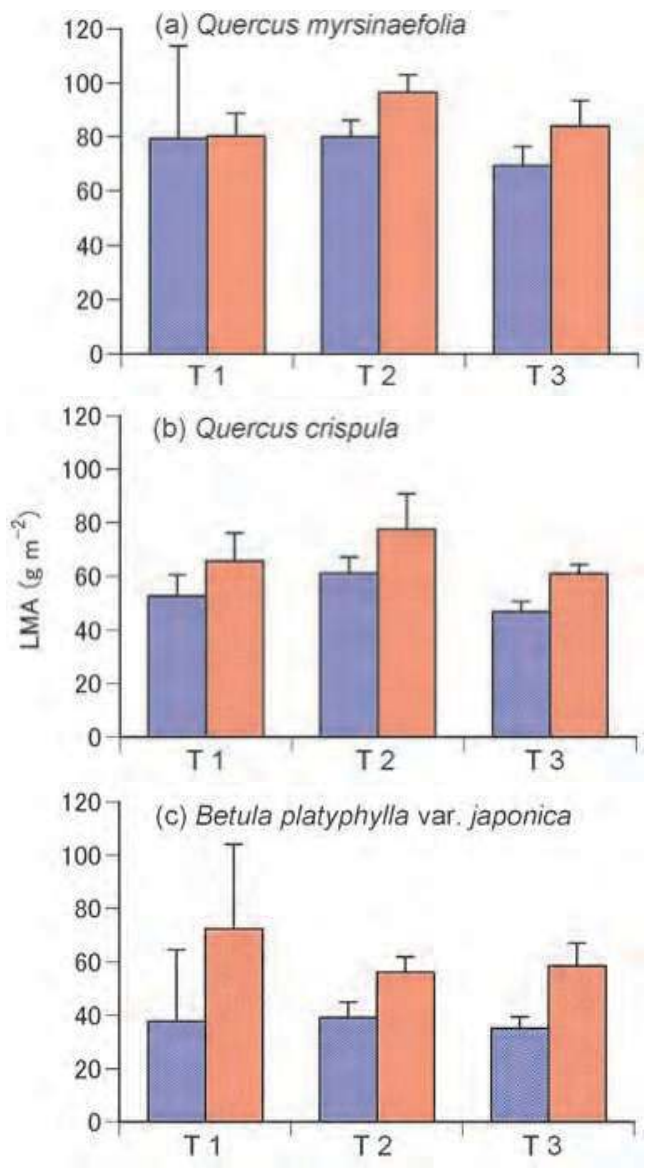

Fig. 5. Leaf mass per area (LMA) for the three species at the three temperature and two light conditions. Blue and red bars indicate L1 and L2 light conditions, respectively. Mean values with positive standard deviations are shown.

\subsection{Photochemical efficiency of $Q$. myrsinaefolia}

Values of photochemical efficiency (Fv/Fm) differed, according to temperature and light conditions and season (Fig. 6). In August of 2009, Fv/Fm values were similar between the two light conditions for the three temperature conditions. Although Fv/Fm value was about 0.8 at T3 in August, Fv/Fm values slightly decreased as temperature decreased from T3 to T1. Fv/Fm value was about 0.7 at T1 in August of 2009. Fv/Fm value decreased from autumn to winter in each temperature condition. This tendency was more conspicuous at L2 
than L1 in each temperature condition. In addition, Fv/Fm value decreased to almost zero in February at T1, and all seedlings died by March (Fig. 7). By contrast, although Fv/Fm values decreased in winter at $\mathrm{T} 2$ and $\mathrm{T} 3$, these values increased again from spring to summer (Fig. 6) and the seedlings grew well by autumn (Fig. 8).
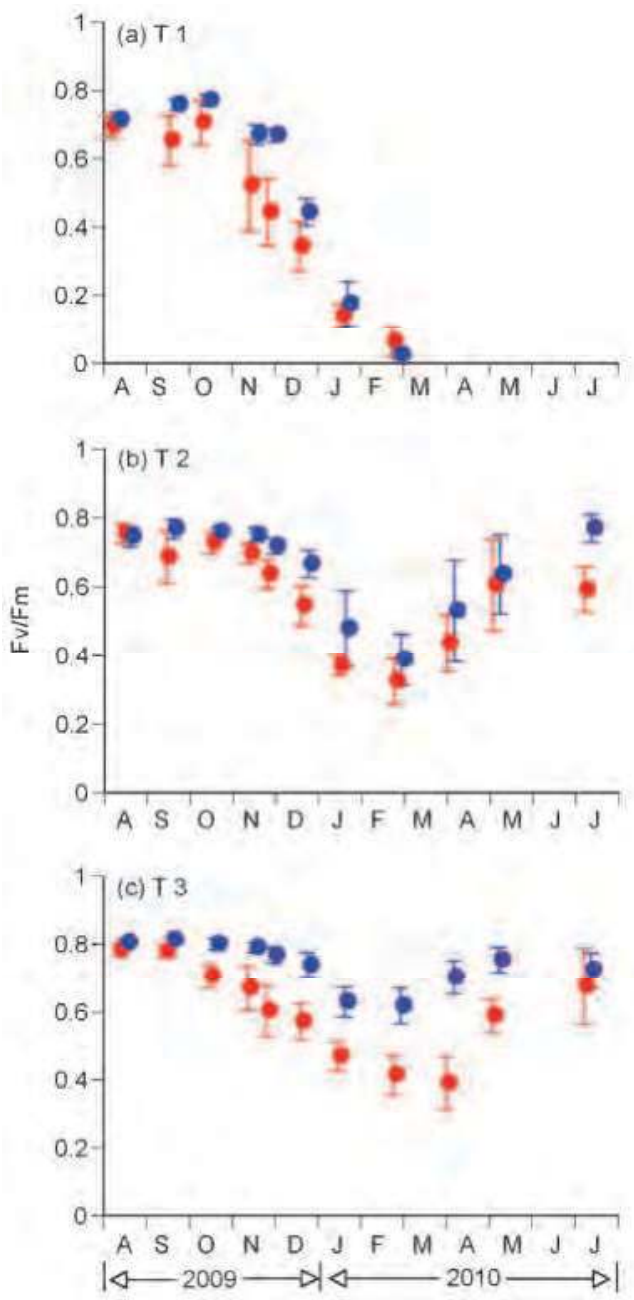

Fig. 6. Seasonal change of Fv/Fm of Quercus myrsinaefolia at three temperature and two light conditions. Blue and red circles indicate L1 and L2 light conditions, respectively. Mean values with standard deviations are shown.

\section{Discussion}

This study showed (1) that high temperature and light conditions increased the current-year seedling growth of the warm-temperate evergreen and the two cool-temperate deciduous 
species, except for the effect of light on stem height, and (2) that high temperature mitigated reduction of photochemical efficiency $(\mathrm{Fv} / \mathrm{Fm})$ of $Q$. myrsinaefolia in winter. Furthermore, winter temperature was so cold at T1 for $Q$. myrsinaefolia that all seedlings of this species died in winter. Therefore, this study showed that high temperature and light conditions increased the seedling growth of the three species and survival of $Q$. myrsinaefolia in winter.
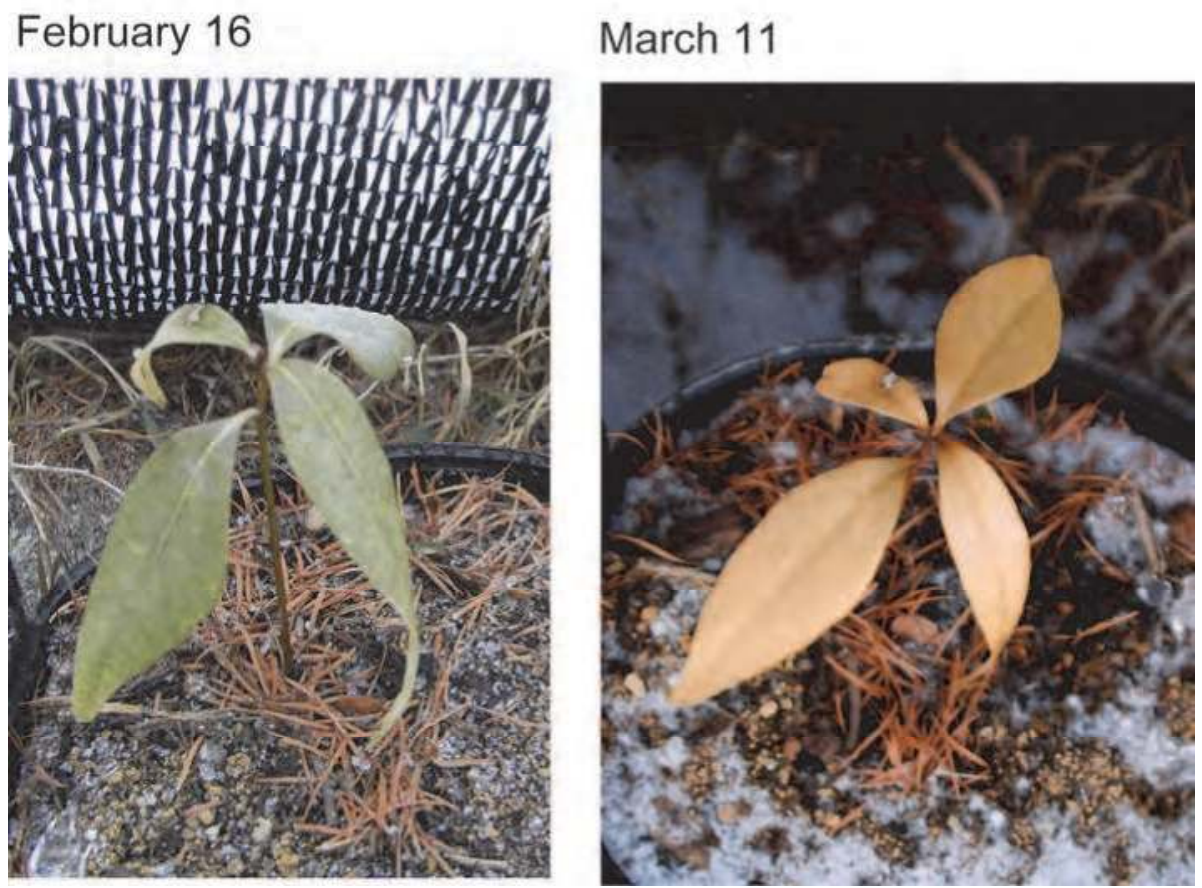

Fig. 7. A current-year seedling of Quercus myrsinaefolia at T1 with L1 light condition on February 16 and March 11, 2010. These photos were taken for a same seedling. Die-back was observed on March 11.

Light conditions did not affect stem height of the three species. Seiwa \& Kikuzawa (1989) also reported that stem height of current-year seedlings was not different between bright and dark conditions for deciduous broad-leaved species with small seeds, while stem height was smaller in bright conditions than dark conditions for those of large seeds. Thus, stem height is not always taller in brighter conditions for current-year seedlings. This may reflect a survival strategy in forests. Litter accumulation on forest floor is a factor reducing seed germination and seedling survival (Goldberg \& Werner, 1983). Therefore, the current-year seedlings germinated below litter layer have to grow over the litter layer. Furthermore, high growth of stem height is also advantageous for survival because of competition with other plants. Therefore, seedlings of the three species would preferentially grow stem height more than stem diameter in dark conditions as compared with bright conditions.

LMA was smaller at darker conditions for the three species at the three temperature conditions, which is advantageous for light capture efficiency per unit leaf mass. LMA of $Q$. myrsinaefolia and Q. crispula was also affected by temperature. Although LMA of the two 
species tended to be greater at T2 than T1 and T3, these differences were not large. By contrast, Woodward (1979) observed that low temperature increased LMA of Phleum bertolonii and P. alpinum because of increase of cell diameter. Unfortunately, this study did not examine cell diameter of leaves at the three temperature conditions. However, it is possible that light dominates the control of LMA of the current-year seedlings of the three species, compared with temperature.

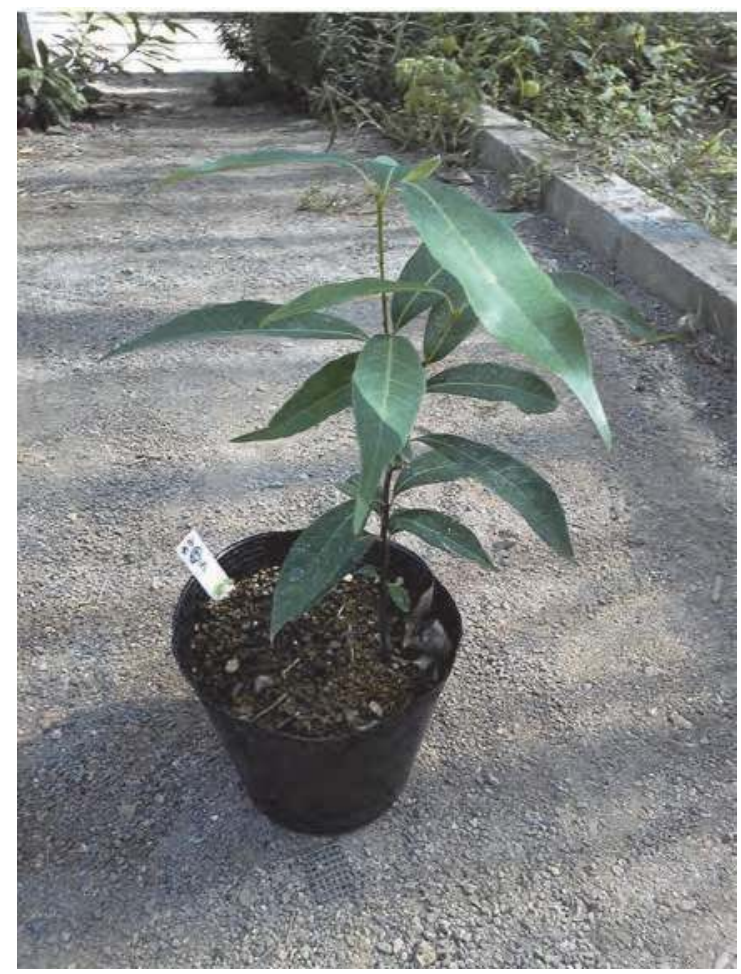

Fig. 8. A 1-year old seedling of Quercus myrsiaefolia at T3 with L1 light condition on October $14,2010$.

Many previous studies about effects of temperatures on plant growth have been conducted so far in cold environments such as alpine region and tundra (Chapin \& Shaver, 1985; Molau, 1997; Arft et al., 1999; Hollister \& Webber, 2000). It is often reported that high temperature increases plant growth in such cold environments (Chapin \& Shaver, 1996; Takahashi, 2005), meaning that cold temperature limits plant growth. Increase of temperature enhances photosynthetic rates in cold environments because of temperature dependency of photosynthetic rates (DeLucia \& Smith, 1987). Furthermore, high temperature throughout a year expands the growth period of plants (Chmielewski \& Rotzer, 2001). Nevertheless, seedling dry mass, stem height and diameter of Q. myrsinaefolia at T3 were similar to or smaller than those at T2 (the temperature conditions of the northern distribution limit). This suggests that temperature during the growth period is not a major factor limiting the growth of $Q$. myrsinaefolia. Northern distribution limits of warm- 
temperate evergreen broad-leaved forests tend to be determined by coldness in winter, not by warmth during the growth period (Kira, 1991). Thus, winter temperature may be important for the distribution of $Q$. myrsinaefolia along latitudinal gradients.

Increase of temperature clearly mitigated reduction of photochemical efficiency (Fv/Fm) of Q. myrsinaefolia during winter. This tendency was more conspicuous at brighter conditions. In forests, seedlings hardly grow in understory dark conditions, and grow vigorously in canopy gaps (Takahashi et al., 2001; Takahashi \& Rustandi, 2006). Therefore, it is suggested that increase of photochemical efficiency of $Q$. myrsinaefolia by increase of temperature would enhance the growth in bright conditions. This effect may be large in the northern distribution limit of $Q$. myrsinaefolia because $Q$. myrsinaefolia co-dominates with many deciduous broad-leaved species there (Otsuka et al., 2004). Much light penetrates into forest floor in winter because of leaf fall of deciduous broad-leaved species. Understory seedlings and saplings of $Q$. myrsinaefolia can assimilate during winter after leaf fall of deciduous broad-leaved species, and the photosynthetic production during winter increases the growth and survival of Q. myrsinaefolia in the understory (Takenaka, 1986). Therefore, increase of winter temperature would enhance the growth and photochemical efficiency of Q. myrsinaefolia in the northern distribution limit.

The growth of the two cool-temperate deciduous broad-leaved species $(Q$. crispula and $B$. platyphylla var. japonica) was greater at T2 and T3 conditions than T1 (the optimal temperature conditions). Many studies showed that tree growth is greater nearer the southern and lower distribution limits along latitudinal and altitudinal gradients, respectively (Persson, 1998; Mäkinen et al., 2000; Li et al., 2003; Takahashi \& Yoshida, 2009). Although the results of the previous studies were conducted in natural distribution ranges, the result of this study showed that tree growth increases in the temperature conditions warmer than the natural distribution range. Drought stress increases near southern and lower distribution limits (Buckley et al., 1997; Takahashi et al., 2003a; Adams \& Kolb, 2005; Hart et al., 2010; Lebourgeois et al., 2010). On the contrary, increase of temperature prolongs the growth period (Sparks et al., 2000; Chmielewski \& Rotzer, 2001; Fujimoto, 2008). Although increase of temperature induces drought stress to some extent, it would increase annual growth of plants by increasing annual carbon gain through increase of growth period.

The high growth of $Q$. crispula and B. platyphylla var. japonica at the two temperature conditions (T2 and T3) warmer than the current distribution range suggests that the natural distribution ranges of the two species are not determined by optimal temperature conditions alone (i.e., the concept of ecological niche). Although Q. crispula is a common species in oldgrowth deciduous broad-leaved forests (Masaki et al., 1992; Takahashi et al., 2003b), Q. crispula is recognized as a gap-dependent species (Yamamoto, 1989). It is reported that saplings of deciduous broad-leaved species distributed mainly in canopy gaps in an evergreen broad-leaved forest (Miura et al., 2001). In deciduous broad-leaved forests, understory saplings increases carbon gain by leafing before leaf expansion of canopy trees (Seiwa \& Kikuzawa, 1996). However, understory of evergreen broad-leaved forests is dark conditions throughout a year, which have restricted saplings of deciduous broad-leaved species into canopy gaps. Therefore, actual distribution ranges are largely affected not only by temperature conditions but also by competition with other species (Takahashi, 2003). 


\section{Conclusion}

This study predicted that high winter temperature mitigates the reduction of photochemical efficiency and reduces winter mortality of $Q$. myrsinaefolia. Furthermore, this study showed that increase of temperature enhances the growth of not only $Q$. myrsinaefolia but also $Q$. crispula and B. platyphylla var. japonica. It is possible that global warming intensifies competition between warm-temperate and cool-temperate broad-leaved species at their latitudinal ecotones. Therefore, it is unclear whether $Q$. myrsinaefolia will gain parts of the habitat now covered by B. platyphylla var. japonica and $Q$. crispula under global warming. This study examined only one warm-temperate broad-leaved species and two cooltemperate broad-leaved species, and the results of this study are not enough to show general responses of the two life forms to temperature and light conditions because of large variations in responses to temperature and light conditions within a life form (Parsons et al., 1994; Takahashi et al., 2003a; van der Werf et al., 2007). Therefore, it is necessary to analyze many species for each life form to clarify general growth responses to temperature and light conditions.

\section{Acknowledgment}

This study was partially supported by grants from the Ministry of Education, Culture, Sports, Science and Technology, Japan (Nos. 19580168, 22580160). We thank Dr. H. Kobayashi for constructive comments.

\section{References}

Adams, H. D. \& Kolb, T. E. (2005) Tree growth response to drought and temperature in a mountain landscape in northern Arizona, USA. Journal of Biogeography, 32, 16291640.

Aranda, I., Castro, L., Alia, R., Pardos, J. A. \& Gil, L. (2005) Low temperature during winter elicits differential responses among populations of the Mediterranean evergreen cork oak (Quercus suber). Tree Physiology, 25, 1085-1090.

Arft, A. M., Walker, M. D., Gurevitch, J., Alatalo, J. M., Bret-Harte, M. S., Dale, M., Diemer, M., Gugerli, F., Henry, G. H. R., Jones, M. H., Hollister, R. D., Jónsdóttir, I. S., Laine, K., Lévesque, E., Marion, G. M., Molau, U., Mølgaard, P., Nordenhäll, U., Raszhivin, V., Robinson, C. H., Starr, G., Stenström, A., Totland, Ø., Turner, P. L., Walker, L. J., Webber, P. J., Welker, J. M. \& Wookey, P. A. (1999) Responses of tundra plants to experimental warming: meta-analysis of the international tundra experiment. Ecological Monographs, 69, 491-511.

Buckley, B. M., Cook, E. R., Peterson, M. J. \& Barbetti, M. (1997) A changing temperature response with elevation for Lagarostrobos franklinii in Tasmania, Australia. Climatic Change, 36, 477-498.

Chapin, F. S., III \& Shaver, G. R. (1985) Individualistic growth response of tundra plant species to environmental manipulations in the field. Ecology, 66, 564-576.

Chmielewski, F. \& Rotzer, T. (2001) Response of tree phenology to climate change across Europe. Agricultural and Forest Meteorology, 108, 101-112.

Danby, R. K. \& Hik, D. S. (2007) Responses of white spruce (Picea glauca) to experimental warming at a subarctic alpine treeline. Global Change Biology, 13, 437-451. 
DeLucia, E. H. \& Smith, W. K. (1987) Air and soil temperature limitations on photosynthesis in Engelmann spruce during summer. Canadian Journal of Forest Research, 17, 527533.

Demmig-Adams, B., Adams, W.I., Winter, K., Meyer, A., Schreiber, U., Pereira, J. S., Krüger, A., Czgan, F. C. \& Lange, O. L. (1989) Photochemical efficiency of photosystem II, photon yield of $\mathrm{O}_{2}$ evolution, photosynthetic capacity, and carotenoid composition during the midday depression of net $\mathrm{CO}_{2}$ uptake in Arbutus unedo growing in Portugal. Planta, 177, 377-387.

Editorial Board of Flora of Nagano Prefecture (1997) Flora of Nagano Prefecture. Shinano Mainichi Shinbunsha, Nagano, Japan (in Japanese).

Ellsworth, D. S. \& Reich, P. B. (1992) Leaf mass per area, nitrogen content and photosynthetic carbon gain in Acer saccharum seedlings in contrasting forest light environments. Functional Ecology, 6, 423-435.

Fujimoto, S. (2008) Estimating the impact of thermal change on broad-leaved tree leaf phenology in the warm temperate zone. Japanese Journal of Conservation Ecology, 13, 75-87 (in Japanese).

Goldberg, D. E. \& Werner, P. A. (1983) The effects of size of opening in vegetation and litter cover on seedling establishment of goldenrods (Solidatgo spp.). Oecologia, 60, 149155.

Gould, K. S. (1993) Leaf heteroblasty in Pseudopanax crassifolius: functional significance of leaf morphology and anatomy. Annals of Botany, 71, 61-70.

Harsch, M. A., Hulme, P. E., McGlone, M. \& Duncan, R. P. (2009) Are treelines advancing? A global meta-analysis of treeline response to climate warming. Ecology Letters, 12, 1040-1049.

Hart, J. L., Gevel, S. L., Sakulich, J. \& Grissino-Mayer, H. D. (2010) Influence of climate and disturbance on the growth of Tsuga canadensis at its southern limit in eastern North America. Trees, 24, 621-633.

Haxeltine, A. \& Prentice, I. C. (1996) BIOME3: An equilibrium terrestrial biosphere model based on ecophysiological constraints, resource availability, and competition among plant functional types. Global Biogeochemical Cycles, 10, 693-709.

Hoch, G. \& Körner, C. (2009) Growth and carbon relations of tree line forming conifers at constant vs. variable low temperatures. Journal of Ecology, 97, 57-66.

Hollister, R. D. \& Webber, P. J. (2000) Biotic validation of small open-top chambers in a tundra ecosystem. Global Change Biology, 6, 835-842.

Holtmeier, F.-K. \& Broll, G. (2007) Treeline advance -driving processes and adverse factors. Landscape Online, 1, 1-33.

Horikawa, Y. (1972) Atlas of the Japanese flora. Gakken, Tokyo, Japan.

Ishigami, Y., Shimizu, Y. \& Omasa, K. (2003) Projection of climatic change effects on potential natural vegetation distribution in Japan. Journal of Agricultural Meteorology, 59, 269-276 (in Japanese).

Kamitani, T. (1993) Ecological studies on regeneration of beech coppice forests in heavy snowfall region. Memoirs of the Faculty of Agriculture, Niigata University, 30, 1-108 (in Japanese).

Kira, T. (1949) Forest zones of Japan. Ringyo Gizyutu Kyokai, Tokyo, Japan (in Japanese).

Kira, T. (1991) Forest ecosystems of east and southeast Asia in a global perspective. Ecological Research, 6, 185-200. 
Kohyama, T. \& Shigesada, N. (1995) A size-distribution-based model of forest dynamics along a latitudinal environmental gradient. Vegetatio, 121, 117-126.

Koike, T. (1988) Leaf structure and photosynthetic performance as related to the forest succession of deciduous broad-leaved trees. Plant Species Biology, 3, 77-87.

Kullman, L. (2002) Rapid recent range-margin rise of tree and shrub species in the Swedish Scandes. Journal of Ecology, 90, 68-77.

Lebourgeois, F., Rathgeber, C. B. K. \& Ulrich, E. (2010) Sensitivity of French temperate coniferous forests to climate variability and extreme events (Abies alba, Picea abies and Pinus sylvestris). Journal of Vegetation Science, 21, 364-376.

Lenoir, J., Gegout, J. C., Marquet, P. A., de Ruffray, P. \& Brisse, H. (2008) A significant upward shift in plant species optimum elevation during the 20th century. Science, 320, 1768-1771.

Li, M. H., Yang, J. \& Krauchi, N. (2003) Growth responses of Picea abies and Larix decidua to elevation in subalpine areas of Tyrol, Austria. Canadian Journal of Forest Research, 33, 653-662.

Mäkinen, H., Nöjd, P. \& Mielikäinen, K. (2000) Climatic signal in annual growth variation of Norway spruce (Picea abies) along a transect from central Finland to the Arctic timberline. Canadian Journal of Forest Research, 30, 769-777.

Masaki, T., Suzuki, W., Niiyama, K., Iida, S., Tanaka, H. \& Nakashizuka, T. (1992) Community structure of a species-rich temperate forest, Ogawa Forest Reserve, central Japan. Vegetatio, 98, 97-111.

Matsuki, S., Ogawa, K., Tanaka, A. \& Hara, T. (2003) Morphological and photosynthetic responses of Quercus crispula seedlings to high-light conditions. Tree Physiology, 23, 769-775.

Miura, M., Manabe, T., Nishimura, N. \& Yamamoto, S. (2001) Forest canopy and community dynamics in a temperate old-growth evergreen broad-leaved forest, south-western Japan: a 7-year study of a 4-ha plot. Journal of Ecology, 89, 841-849.

Molau, U. (1997) Responses to natural climatic variation and experimental warming in two tundra plant species with contrasting life forms: Cassiope tetragona and Ranunculus nivalis. Global Change Biology, 3 (Suppl. 1), 97-107.

Morin, X., Viner, D. \& Chuine, I. (2008) Tree species range shifts at a continental scale: new predictive insights from a process-based model. Journal of Ecology, 96, 784-794.

Munier, A., Hermanutz, L., Jacobs, D. M. \& Lewis, K. (2010) The interacting effects of temperature, ground disturbance, and herbivory on seedling establishment: implications for treeline advance with climate warming. Plant Ecology, 210, 19-30.

Namikawa, K., Ishikawa, Y. \& Sano, J. (1997) Stand dynamics during a 12-year period in a second-growth stand in a cool temperate forest in northern Japan. Ecological Research, 12, 277-287.

Niinemets, Ü., Kull, O., Tenhunen, J. D. (1999) Variability in leaf morphology and chemical composition as a function of canopy light environment in coexisting deciduous trees. International Journal of Plant Science, 160, 837-848.

Okuyama, S. (1982) Wild plants in Japan (spring to early summer), Seibundo-Shinkosha Publishling Co., Tokyo, Japan (in Japanese).

Otsuka, K. \& Ozeki, M. (2008) Monitoring of warm-temperate evergreen broad-leaved species Quercus myrsinaefolia in Nagano Prefecture, In: Investigation report for the 
actual conditions of global warming at Nagano Prefecture, 35-41, Nagano Environmental Conservation Research Institute, Nagano, Japan (in Japanese).

Otsuka, K., Ozeki, M. \& Maekawa, M. (2004) Distribution of Quercus myrsinaefolia Blume (Fagaceae), escaped evergreen broad-leaved tree, in mid and downstream region of the Chikuma River, northern Nagano Prefecture. Bulletin of Nagano Environmental Conservation Research Institute, 7, 17-22 (in Japanese).

Parsons, A. N., Welker, J. M., Wookey, P. A., Press, M. C., Callaghan, T. V. \& Lee, J. A. (1994) Growth responses of four sub-Arctic dwarf shrubs to simulated environmental change. Journal of Ecology, 82, 307-318.

Penuelas, J., Ogaya, R., Boada, M. \& Jump, A. S. (2007) Migration, invasion and decline: changes in recruitment and forest structure in a warming-linked shift of European beech forest in Catalonia (NE Spain). Ecography, 30, 829-837.

Persson, B. (1998) Will climate change affect the optimal choice of Pinus sylvestris provenances? Silva Fennica, 32, 121-128.

Samejima, J. (1979) Useful hard-wood in Hokkaido and its characters for improvement (II). Forest Tree Breeding of Hokkaido, 22, 6-14 (in Japanese).

Seiwa, K. \& Kikuzawa, K. (1989) Seasonal growth patterns of seedling height in relation to seed mass in deciduous broad-leaved tree species. Japanese Journal of Ecology, 39, 515 (in Japanese).

Seiwa, K. \& Kikuzawa, K. (1996) Importance of seed size for the establishment of seedlings of five deciduous broad-leaved tree species. Vegetatio, 123, 51-64.

Sparks, T. H., Jeffree, E. P. \& Jeffree, C. E. (2000) An examination of the relationship between flowering times and temperature at the national scale using long-term phenological records from the UK. International Journal of Biometeorology, 44, 82-87.

Takahashi, K. (2003) Effects of climatic conditions on shoot elongation of alpine dwarf pine (Pinus pumila) at its upper and lower altitudinal limits in central Japan. Arctic, Antarctic, and Alpine Research, 35, 1-7.

Takahashi, K. (2005) Effects of artificial warming on shoot elongation of alpine dwarf pine (Pinus pumila) on Mt. Shogigashira, central Japan. Arctic, Antarctic, and Alpine Research, 37, 620-625.

Takahashi, K., Azuma, H. \& Yasue, K. (2003a) Effects of climate on the radial growth of tree species in the upper and lower distribution limits of an altitudinal ecotone on Mt. Norikura, central Japan. Ecological Research, 18, 549-558.

Takahashi, K., Mitsuishi, D., Uemura, S., Suzuki, J. \& Hara, T. (2003b) Stand structure and dynamics during a 16-year period in a sub-boreal conifer-hardwood mixed forest, northern Japan. Forest Ecology and Management, 174, 39-50.

Takahashi, K. \& Rustandi, A. (2006) Responses of crown development to canopy openings by saplings of eight tropical submontane forest tree species in Indonesia: a comparison with cool temperate trees. Annals of Botany, 97, 559-569.

Takahashi, K., Seino, T. \& Kohyama, T. (2001) Responses to canopy openings in architectural development of saplings in eight deciduous broad-leaved tree species. Canadian Journal of Forest Research, 31, 1336-1347.

Takahashi, K., Seino, T. \& Kohyama, T. (2005) Plastic changes of leaf mass per area and leaf nitrogen content in response to canopy openings in saplings of eight deciduous broad-leaved tree species. Ecological Research, 20, 17-23. 
Takahashi, K. \& Yoshida, S. (2009) How the scrub height of Pinus pumila decreases at the treeline. Ecological Research, 24, 847-854.

Takenaka, A. (1986) Comparative ecophysiology of two representative Quercus species appearing in different stages of succession. Ecological Research, 1, 129-140.

Taneda, H. \& Tateno, M. (2005) Hydraulic conductivity, photosynthesis and leaf water balance in six evergreen woody species from fall to winter. Tree Physiology, 25, 299306.

Thuiller, W. (2003) BIOMOD - optimizing predictions of species distributions and projecting potential future shifts under global change. Global Change Biology, 9, 1353-1362.

van der Werf, G. W., Sass-Klaassen, U. G. W. \& Mohren, G. M. J. (2007) The impact of the 2003 summer drought on the intra-annual growth pattern of beech (Fagus sylvatica L.) and oak (Quercus robur L.) on a dry site in the Netherlands. Dendrochronologia, $25,103-112$.

Way, D. A. \& Sage, R. F. (2008) Elevated growth temperatures reduce the carbon gain of black spruce [Picea mariana (Mill.) B.S.P.]. Global Change Biology, 14, 624-636.

Woodward, F. I. (1979) The differential temperature responses of the growth of certain plant species from different altitudes. II. Analyses of the control and morphology of leaf extension and specific leaf area of Phleum bertolonii D.C. and P. alpinum L. New Phytologist, 82, 397-405.

Yamamoto, S. (1989) Gap dynamics in climax Fagus crenata forests. Botanical Magazine, Tokyo, 102, 93-114.

Yin, H., Lai, T., Cheng, X., Jiang, X. \& Liu, Q. (2008) Warning effect on growth and physiology of seedling of Betula albo-sinensis and Abies faxoniana under two contrasting light conditions in subalpine coniferous forests of western Sichuan, China. Journal of Plant Ecology, 32, 1072-1083. 


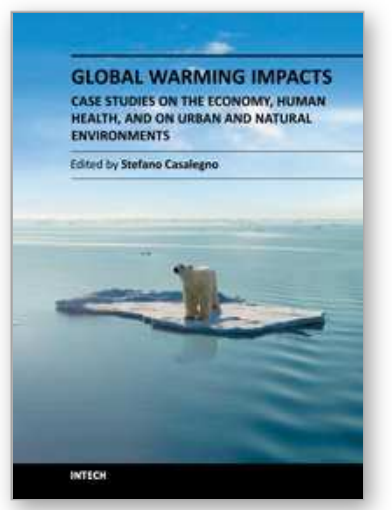

\author{
Global Warming Impacts - Case Studies on the Economy, Human \\ Health, and on Urban and Natural Environments \\ Edited by Dr. Stefano Casalegno
}

ISBN 978-953-307-785-7

Hard cover, 290 pages

Publisher InTech

Published online 03, October, 2011

Published in print edition October, 2011

This book addresses the theme of the impacts of global warming on different specific fields, ranging from the regional and global economy, to agriculture, human health, urban areas, land vegetation, marine areas and mangroves. Despite the volume of scientific work that has been undertaken in relation to each of each of these issues, the study of the impacts of global warming upon them is a relatively recent and unexplored topic. The chapters of this book offer a broad overview of potential applications of global warming science. As this science continues to evolve, confirm and reject study hypotheses, it is hoped that this book will stimulate further developments in relation to the impacts of changes in the global climate.

\title{
How to reference
}

In order to correctly reference this scholarly work, feel free to copy and paste the following:

Koichi Takahashi, Hiroyuki Kobori and Tatsuyuki Seino (2011). Effects of Temperature and Light Conditions on Growth of Current-Year Seedlings of Warm-Temperate Evergreen Tree Species and Cool-Temperate Deciduous Tree Species, Global Warming Impacts - Case Studies on the Economy, Human Health, and on Urban and Natural Environments, Dr. Stefano Casalegno (Ed.), ISBN: 978-953-307-785-7, InTech, Available from: http://www.intechopen.com/books/global-warming-impacts-case-studies-on-the-economy-human-healthand-on-urban-and-natural-environments/effects-of-temperature-and-light-conditions-on-growth-of-currentyear-seedlings-of-warm-temperate-ev

\section{INTECH}

open science | open minds

\section{InTech Europe}

University Campus STeP Ri

Slavka Krautzeka 83/A

51000 Rijeka, Croatia

Phone: +385 (51) 770447

Fax: +385 (51) 686166

www.intechopen.com

\section{InTech China}

Unit 405, Office Block, Hotel Equatorial Shanghai

No.65, Yan An Road (West), Shanghai, 200040, China

中国上海市延安西路65号上海国际贵都大饭店办公楼 405 单元

Phone: +86-21-62489820

Fax: $+86-21-62489821$ 
(C) 2011 The Author(s). Licensee IntechOpen. This is an open access article distributed under the terms of the Creative Commons Attribution 3.0 License, which permits unrestricted use, distribution, and reproduction in any medium, provided the original work is properly cited. 